\title{
An Evaluation of Financial Health of Nigerian Deposit Money Banks using CAMELS Rating Model
}

\author{
Babatunde Rahman YUSUF ${ }^{\star}$, Jamiu Olakunle TIJANI ${ }^{\star \star}$
}

\begin{tabular}{l}
\hline \multicolumn{1}{c}{ A R T I C L E I N F O } \\
\hline Article history: \\
Accepted March 2019 \\
Available online April 2019 \\
\hline JEL Classification \\
M49, N27 \\
Keywords: \\
CAMELS; Operating Licence; \\
Systemic Importance; Operating \\
Structure; Financial Health; \\
Deposit Money Banks
\end{tabular}

\begin{abstract}
A B S T R A C T
This study evaluates the financial health of Deposit Money Banks (DMBs) in Nigeria using CAMELS Rating Model based on three characteristics. Using ex-post facto research design, secondary data which covers years 2010 to 2017 were collected from the annual reports of the selected listed DMBs. Guided by three research objectives, the study formulates and tests three hypotheses. Mean and independent sample t-test are employed to present and analyse the data. The paper, inter alia, provides evidence of a statistically significant difference between the financial health of Domestic-Systemically Important and DomesticNon-Systemically Important DMBs in Nigeria $\left(\mathrm{t}_{\mathrm{cal}}(10)=2.832>\mathrm{t}_{\mathrm{tab}}=2.228 ; p\right.$-value $=0.018$ ). Based on these findings, the paper concludes that the financial health of DMBs do not differ based on the type of operating licence they hold and the structure they operate. The study recommends that Central Bank of Nigeria should tighten its prudential guidelines on DMBs in Nigeria.
\end{abstract}

(C) 2019 EAI. All rights reserved.

\section{Introduction}

The banking sector is a fundamental part of the financial architecture of any economy. The sector makes critical contributions to a nation's pursuit of economic growth and development, through the facilitation of the process of capital formation, monetary policy transmission and management, credit intermediation process, payment and settlement systems, amongst others (Said \& Tumin, 2011, cited in Azizi \& Sarkani, 2014; Scrinivasan \& Saminathan, 2016; Chaudhuri, 2018). Their intermediation function serves as the backbone and catalyst for the growth of an economy (Funso, Kolade \& Ojo, 2012; Jain and Jaiswal, 2016). As the financial health of an economy is intertwined with that of its banking system (Chaudhuri, 2018; Samuel, 2018), it is unimaginable to visualise a modern economy bereft of the services of a bank (Rahman\& Islam, 2018).

By virtue of the services they render and their roles in the economy, banks tend to have many, yet diverse, stakeholders (such as depositors, borrowers, government, employees, auditors, to mention but a few) who affect and are affected by the activities of these banks, whose performances should be evaluated, as doing this provide the stakeholders with flow of information necessary to guide their decision-making process. When these banks are unsound, unstable and unhealthy, these stakeholders' interests are jeopardised. The considerable sizes and increasing complexities in structures and operations of DMBs, precipitated by the effect of intensifying globalisation can only heighten the concerns of these stakeholders. Therefore, it becomes crucial to continually $\mathrm{x}$-ray the performances of these banks with a view to determining their state of health in order to help the stakeholders differentiate good banks from bad ones (Rahman \& Islam, 2018). The scores of performance evaluation frameworks that exist in literature and practice, and with which the financial conditions of banks can be determined has made the task very daunting. However, one of the evaluation paradigms that have gained global traction and over which there appears to be great consensus on its potency is "CAMELS rating model".

Critics of the 2004 consolidation of Nigerian banks have stridently argued that the "near monopoly" created by the exercise has engendered "too-big-to-fail" financial institutions with systemic attributes and vulnerabilities, thereby laying the foundation for deeper banking sector crises in the future (Lucky \& Akani, 2017). And true to their prognosis, within five years of the conclusion of the consolidation exercise and precipitated by the global financial crises of 2007-2008, some Nigerian banks were discovered in 2009 to have had acute financial ill-health, resulting in their nationalisation and the establishment of Assets Management Corporation of Nigeria (AMCON) as a resolution vehicle.

\footnotetext{
`, ${ }^{\star \star}$ Lagos State University, Lagos, Nigeria. E-mail addresses: babatunde.yusuf@lasu.edu.ng (B. R. Yusuf), olakunle.tijani@lasu.edu.ng (J. O. Tijani - Corresponding author)
} 
With the takeover of Skye Bank by the Central Bank of Nigeria (CBN) in 2018, due to the bank's inability to "meet minimum thresholds in critical prudential and adequacy ratios, which culminated in the bank's permanent presence at the CBN Lending Window" (Premium Times, 2018), it stands to reason that the advent of AMCON has not completely taken away, the risk of bank failure, as some Deposit Money Banks (DMBs) in Nigeria continue to show signs of financial frailties. The large size, complexity of structures and interconnectedness of the DMBs have only compounded this risk. According to Kumbirai and Webb (2010), as banks are interconnected with each other for the payment and other functions, the failure of a bank will not only affect its shareholders, depositors, amongst other stakeholders, it may also have effect on the stakeholders in other banks due to contagion effect. In any case, if twelve (12) of the listed DMBs had asset and deposit base of N27.55 trillion and N17.06 trillion, respectively (Annual Reports, 2017), one can only imagine the cataclysmic negative effect on the Nigerian economy, should these institutions fail.

The preponderance of evidence on banking crises in Nigeria have shown that, not only do DMBs often take excessive risks but the risk differ across banks (Iheanyi \& Sotonye, 2017), resulting in significant decline in stock market indices and deterioration of asset quality of most DMBs in Nigeria (Adeusi, Akeke, Adebisi \& Oladunjoye, 2014). It is therefore imperative that the performances of the DMBs be kept under close surveillance at all times (Echekoba, Egbunike \& Ezu, 2014). One of the ways this can be achieved is by obtaining information from regular evaluation of their financial health and soundness using tools such as CAMELS Rating Model, the application of which, Lucky and Akani (2017) have argued, is still at the rudimentary stage in empirical studies in Nigeria.

Studies such as Chien and Danw (2004), Suresh and Bardastani (2016), Echekoba, Egbunike and Ezu (2014), Rozzani, and Abdul Rahman (2013) Bodla and Verma (2006), Yuksel, Dincer and Hacioglu (2015), Dash and Das (2009), Anteneh, Arega and Yonas, (2011), Mulualem (2015), Srinivasan and Saminathan (2016), Rahman and Islam (2018), Iheanyi and Sotonye (2017), Echekoba, Egbunike and Ezu (2014), Manju and Askok (2017); Lucky and Akani (2017), Onyema, Okey, Precious and Amadi (2018) have used CAMELS Rating Model to evaluate the financial performance of banks under different research settings and focus. Supporting this position, Rahman and Islam (2018) argued that previous cognate studies on performance evaluation using CAMELS have different perspectives, focused on different periods and countries. It is instructive that some of these papers have weak research designs, controversial methodologies and findings, thereby creating a research gap.

Moreover, in response to the negative effects of the 2007-2008 global financial crisis on the Nigeria banking sector and as part of measures geared at reforming the Nigerian financial system, enhance quality of banks and promote a healthy financial sector, the Central Bank of Nigeria reviewed and consequently phased out the Universal Banking Model in 2010. These reforms and initiatives have resulted in DMBs having certain characteristics based on operating license, operating structure and systemic importance. Based on operating licence, they are classified into regional, national and international categories. Based on operating structure, they are grouped into financial holding companies and non-financial holding companies, while based on systemic importance, they are classified as Domestic-Systemically Important Banks (D-SIB) and DomesticNon-Systemically Important Banks (D-NSIB). Despite the plethora of related studies, there still exists, very scanty literature and evidence on the use of CAMELS Rating Model in comparatively evaluating the financial health of listed Deposit Money Banks based on these characteristics, particularly in Nigeria. This has consequently created further research gap. It is in the light of the foregoing that this study evaluates the financial health of listed Deposit Money Banks in Nigeria using the CAMELS Rating Model based on three identified bank characteristics. In this regard, this study investigates whether there is a significant difference between the financial health of International and National Licenced Deposit Money Banks in Nigeria; assess whether there is a significant difference between the financial health of Holding and Non-Holding Company Structured Deposit Money Banks in Nigeria and examine whether there is a significant difference between the financial health of Domestic-Systemically Important and Domestic-Non-Systemically Important Deposit Money Banks in Nigeria.

The study will add to the reservoir of information at the disposal of the Central Bank of Nigeria (CBN) on the level of financial fitness of the DMBs, as this will help the regulator to proactively and effectively discharge its supervisory responsibilities in order to enthrone and entrench a sound financial system. For would-be and current investors, the findings of the study will guide them in deciding in which bank to invest when they are constructing their portfolios. The study will also enrich cognate literature from which future studies can draw.

The rest of the paper is structured as follows: section 2 focuses on literature review and hypotheses development; section three describes the research methods employed; section four deals with results and discussions, while section five concludes the paper.

\section{Literature Review \& Hypotheses Development}

The CAMELS Rating system was developed in 1979 in the United States as a supervisory rating system with which the overall financial conditions of banks are evaluated (Federal Financial Institutions 
Examination Council, 1979). It is also called “Uniform Financial Institutions Rating System (UFIRS)". Although, its root can be traced to the U.S., it has gained global adoption and acceptance among comity of bank regulators, the world over, following a recommendation by the U.S Federal Reserve Bank (Manju \& Ashok, 2017). It is a system for on-site examination of banking institutions which ensures a bank's health condition is x-rayed and reviewed using hybrid performance metrics, based on variety of information sources such as financial statement, funding sources, macro-economic data, budget and cash flow (Opez 1999; Altan, Yusufazari \& Beduk 2014; Chaudhuri, 2018).

Following the financial crisis of 2007-2008 and the consequent nationalisation of some banks, the Central Bank of Nigeria repealed the Universal Banking Model adopted by Nigerian banks. It is believed that this banking system, otherwise called "financial supermarket", contributed to the banks' loss of operational and strategic focus, exposure to greater risks that challenge the stability of the financial system and encouraged financial recklessness. Universal Banking system is a banking model that allows commercial banks to offer wide-range of non-core banking services such as asset management, insurance, nominee, pension fund administration, proprietary trading, re-insurance services, loss adjusting services amongst others, together with the banking business for which they were licenced. To give effect to the above repeal, Regulations No. 01, 2010 which centres on CBN Scope, Conditions \& Minimum Standards for Commercial Banks was issued by the CBN on 7 September, 2010. Part 2 of this Regulations empowers the Governor of the Central Bank of Nigeria to issue a commercial banking licence upon such terms and conditions which authorise the operation of a Commercial Bank on a regional, national or international basis.

According to the Regulation, a Commercial Bank with regional banking license is expected to carry on its banking business operations within contiguous States of the Federation, not less than six (6) but not more than twelve (12), which are within not more than two (2) Geo-Political Zones of the Federation, as well as within the Federal Capital Territory. Any bank with this licence is required to maintain a minimum paid-up share capital of Ten Billion Naira (N10,000,000,000.00) or such other amount as may be prescribed by the CBN from time to time and are also prohibited from carrying out settlement bank activities. Banks such as Suntrust Bank Nigeria Limited and Providus Bank Plc have regional banking authorisation (CBN, 2017). A Commercial Bank with national banking licence is permitted to undertake banking business operations in all the States of the Federation including the Federal Capital Territory, maintain a minimum paid-up share capital of Twenty Five Billion Naira (N25,000,000,000.00) or such other amount as may be prescribed by the CBN from time to time. Banks with national banking licence include: Citi, Ecobank, Heritage, Keystone, StanbicIBTC, Standard Chartered, Sterling, Unity and Wema.

However, a Commercial Bank is deemed to hold an international banking authorisation where it is permitted to carry on its banking business operations within all the States of the Federation, as well as to establish and maintain offshore banking operations in jurisdictions of its choice, subject to the approval of the $\mathrm{CBN}$ and compliance with regulatory requirements of host country. Such banks are required to maintain a minimum paid-up share capital of Fifty Billion Naira (N50,000,000,000.00) or such other amount as may be prescribed by the CBN from time to time. Banks with international banking authorisation include: Access, Diamond, Fidelity, First City Monument Bank, First Bank, Guaranty Trust, Skye, Union, United Bank for Africa and Zenith. Regardless of the licence a DMB holds, it is duty-bound to comply with all prudential guidelines and regulations issued by the CBN on the required level of capital adequacy, liquidity and cash reserve.

As part of the review of the Universal Banking model, CBN envisages that some banks/banking group may express preference for the retention of non-core banking businesses. For this reason, the regulator directed that it will be a requirement to evolve into a holding company model where a non-operating HoldCo holds the investments in the bank and each non-core banking operation in a subsidiary arrangement (SubCo). According to the CBN Circular to all Banks and Discount Houses on Review of Universal Banking Model (2010):

Such banks/banking group are then required to comply with CBN requirements for the establishment of HoldCos which will include a detailed business case for engaging in any non-core banking operation. The business case will include the corporate and risk management frameworks that should be put in place to demonstrate how depositors' funds from core banking business will be ring-fenced from non-core banking business (CBN, 2010)

Under the HoldCo arrangement, as required by the Circular, subsidiary banks are licensed and regulated by the CBN, while the operating Subcos (non-bank subsidiaries of HoldCO ) are licensed and regulated by the relevant functional regulator. It is instructive to also add that the Holdco is licensed by the CBN as an Other Financial Institution (OFI) under BOFIA. The HoldCo will also domiciled in Nigeria.

Systematically Important Banks are those banks whose distress or failure, as a result of their size, complexity and systemic interconnectedness, are of such significance that they can disrupt the wider financial architecture and, by extension, the economic activity in the country (Central Bank of Nigeria, 2014). The Framework for Supervision of Domestic Systematically Important Banks in Nigeria, inter alia, designated the following banks as Domestic Systematically Important Banks: are First Bank of Nigeria Limited, Guaranty Trust Bank Plc, Zenith Bank Plc, United Bank for Africa Plc (UBA), Access Bank Plc, Skye Bank Plc, Ecobank 
Nigeria and Diamond Bank Plc. According to this Framework, these banks are required to maintain 16 per cent minimum Capital Adequacy Ratio, while also holding more liquid assets and a liquidity ratio of 35 per cent. This presupposes that the affected banks were expected to have a minimum liquidity ratio, which is five per cent above the 30 per cent requirement in the industry.

Based on industry data, eight banks, measured in terms of size, account for more than 70 per cent of the industry's total asset, credits and deposit liabilities, in addition to their constituting more than 60 per cent of the industry net-interbank transactions (Premium Times, 2013). To limit the economic impact of bank distress that the phenomenal size of these banks can have, especially on the real sector of the economy, the Framework provides that these banks develop and submit to the CBN at the beginning of every year, "contingency and resolution plans that incorporate resolution and winding-down plan, in addition to quarterly disclosures of their financial condition and risk management activities, while their operations are closely monitored and regulated."

This paper employed General Regulation and Stakeholders' theories to understand why performance evaluation of Deposit Money Banks is important and the role of the monetary authorities. These theories are as discussed below:

\section{Stakeholders' Theory}

Stakeholder theory questions the traditional assumption that management of business concerns such as banks should focus only on the goal of pursuit of profit which according to Jensen (2002), is the "singlevalued objective" of any corporation. It is also important because it seeks to address the often overlooked, yet pertinent sociological question of how corporations affect society (Hinings \& Greenwood, 2003; Stern \& Barley, 1995; Laplume, Sompar \& Litz, 2008). Freeman was first to fully articulate the stakeholder framework in his seminal book, Stakeholder Management: A Stakeholder Approach, in 1984. The theory draws strength on the literatures on corporate planning, systems theory and corporate social responsibility, amongst others.

A stakeholder-based Deposit Money Banks serve the interests of, not only shareholders but other subjects (such as depositors, personnel, creditors, borrowers, suppliers, local community, authorities, environment, business partners, and so on) who have relationship that are critical to the success of the banks. These banks, therefore, are duty-bound to create value, in a balanced and satisfactory way, for all their stakeholders (Marco \& Luciano, 2015). Stakeholders' theory is relevant to this study because Deposit Money Banks in Nigeria have various stakeholders such as employees, depositors, borrowers, suppliers, the environment and even the monetary authorities. The activities of these banks tend to affect these stakeholders, such as it would be expected in other climes. When these institutions fail or are unable to effectively and efficiently carry out their activities, the brunt of the negative consequences is borne by the stakeholders. One way to avoid this scenario is to keep tap on the performances of the DMBs.

\section{General Regulation Theory}

Sinkey (1992) is a theoretician acknowledged to be the first to have attempted to develop a general theory of regulation (Currie, 2005). The Regulation Theory combines agency theory which focuses on problems of hidden actions (otherwise called "moral hazards") and hidden information (otherwise called "adverse selection"), with a theory of production of regulatory and financial services where output is dependent on two variables of confidence and convenience. According to Sinkey (1992) cited in Currie(2006), the role and importance of government guarantees are evident in a situation where an institution is distressed. In the light of the confidence function, a distressed institution is characterised by low and negative net worth, unstable earnings, amongst other negative performance pointers, all of which provide testament of a breakdown in agency relationship, resulting in increased financial risk (Currie, 2005).

The general theory of regulation is driven by the need to recognise that regulation is required to prevent the price and output volatility that can lead to financial crises, resulting in declining or negative economic growth; and that regulation is multi-faceted and also involves establishing a regulatory model, the role of which is to contain and mould the risk taking and management behaviour of both financial and nonfinancial institutions as well as other participants through prudential supervisory system appropriate to the strength or weaknesses of the protective measures. The adoption of this theory by this paper is justified against the background that regulatory failure is usually a precursor to the failure of banking institutions, which triggers financial crises and that, unless the regulator is alive to its responsibility, the problem gets festered and the wider economy is negative affected.

Previous cognate studies have been carried out but with somewhat controversial methodologies and findings. Suresh, Chithra, \& Bardastani (2016) employed CAMEL ranking model to evaluate and compare the performance of Retail Conventional and Islamic banks in Bahrain between 2007-2014. The study revealed that islamic banks are not as profitable and efficient as retail conventional banks. They attributed this finding to inherent institutional factors. Echekoba, Egbunike \& Ezu (2014), using ordinary least square method, examined the impact of CAMEL parameters on the profitability of Nigerian commercial banks for the period 
which spanned 2001-2010. Their study showed that capital adequacy, assets quality, management efficiency and earnings have no influence on profitability, while liquidity parameter significantly influence the profitability of banks

Rahman and Islam (2018) comparatively evaluated the performances of seventeen Bangladeshi Private Commercial Bank using CAMEL rating framework. Secondary data which spanned 2010-2016 were collected from their annual reports. Findings showed that Eastern bank stood at the top position amidst the seventeen selected private commercial banks. Srinivasan and Saminathan (2016) analysed the performances of 25 Public, 18 Private and 8 Foreign Sector Banks in India using Camel Model Analysis. Results of the study showed that public sector banks (namely: Andhra Bank, Bank of Baroda, Allahabad Bank, Punjab National Bank IDBI Bank, State Bank of Bikaner and Jaipur and UCO Bank) were ranked at the top five positions in their financial performance during the study period. Iheanyi and Sotonye (2017) assessed the Performance of Nigeria's Bank through Camel Model using 19 years data which were collected and analyzed through ordinary least square. Results show that capital adequacy, management efficiency, earning and liquidity have no significant impact on the profitability of the banks, while assets quality has a negative impact on that profitability of the banks. Onyema, Okey, Precious \& Amadi (2018) evaluated the financial soundness of ten commercial banks in Nigeria using Bankometer S-score model, unlike others that employed CAMELS framework or CLSA-Stress test. Secondary Data were gathered for fifteen years (2000-2015). Results revealed that 2 banks are at the top of the list with scores greater than 70 (126 and 113 respectively), presupposing that they are sound and healthy, whereas eight of the banks have their scores below fifty, suggesting that they are experiencing financial difficulties and carry high risk.

It flows from the foregoing review that a literature gap exists on the comparative evaluation of the performance of Deposit Money Banks in Nigeria using CAMELS rating model based on bank attributes such as type of operating licence, operating structure and systemic importance, on the basis of which the following hypotheses were formulated and tested:

\section{Hypothesis One:}

Ho: There is no significant difference between the financial health of International and National Licenced Deposit Money Banks in Nigeria.

\section{Hypothesis Two:}

Ho: There is no significant difference between the financial health of Holding and Non-Holding Company Structured Deposit Money Banks in Nigeria.

\section{Hypothesis Three \\ Ho: There is no significant difference between the financial health of Domestic-Systemically Important and Domestic-Non-Systemically Important Deposit Money Banks in Nigeria.}

\section{Research Methods}

This paper employs ex-post facto research design, the justification of which rests on the fact it involves the study and quantitative analysis of historical facts arising from events, activities and phenomena that have occurred (Osuagwu, 2006; Cooper and Schindler, 2014; Kothari \& Garg, 2016). Focused on listed Deposit Money Banks (DMBs) in Nigeria, the population of which was fifteen (15) as at 31 December, 2017 (Daily Official List, 31 December, 2017), secondary data were gathered from the annual reports of twelve (12) of these banks selected after applying filters on the population, based on availability and usability of complete data set. At $80 \%$, the selected banks are considered representative enough to allow for generalisation of findings. The study is delineated to cover a period of eight years which spanned 2010 to 2017.

The choice of year 2010 as the start year is informed by the fact that it was the year after which the Central Bank of Nigeria phased out the Universal Banking Model and introduced new commercial banking model with different categorisations such as regional banking model, national banking model, international banking, financial holding companies, amongst others. These new banking paradigms give the DMBs in Nigeria different operational and strategic characteristics. For instance, on the one hand, while some banks operate using regional and national licences, others operate with international authorisation. On the other hand, some of these DMBs adopted the holding company structure, others settled for non-holding company structure. Furthermore, some DMBs are designated as Domestic Systemically Important Banks, while others are Domestic Non-Systemically Banks by the Central Bank of Nigeria (See table 2). These features are grouped under three headings of type of operating licence, type of operating structure and systemic importance.

Using these attributes, the study comparatively evaluates and rates the financial health of these DMBs using a hybrid financial performance metrics, acronymically represented as CAMELS (C-Capital Adequacy; A- Asset Quality; M-Management Efficiency; E-Earnings Quality; L-Liquidity and S-Sensitivity to Market Risk. Consistent with the studies of Reddy (2012), Srinivasan and Saminathan (2016) and Rahman 
and Islam (2018), this paper proxied and measured each of the above performance metrics with more than one sub-metrics, the composite scores of which are used to rank the DMBs. These metrics, sub-metric, measurement, sub-metric weights and composite weights are as provided in table 1.

The financial health of the listed DMBs are evaluated based on three characteristics of type of operating license, operational structure and systemic importance. Independent sample t-test of significance is used to test the three formulated hypotheses, while descriptive statistics such as mean are employed to present some stylized fact about these banks. The equality of variances and normality of the gathered data which are preconditions that must be satisfied before the use of independent samples t-test are also established using Levene's test for Equality of Variances and Shapiro-Wilk respectively.

Table 1: Operational Definition of Metric and Sub-Metrics of CAMELS Ranking Model

\begin{tabular}{|c|c|c|c|c|}
\hline $\begin{array}{c}\text { Financial } \\
\text { Soundness Metric }\end{array}$ & $\begin{array}{c}\text { Financial } \\
\text { Soundness Sub-Metric }\end{array}$ & $\begin{array}{l}\text { Measurement of Financial Performance Sub- } \\
\text { Metric }\end{array}$ & $\begin{array}{c}\text { Sub-Metric } \\
\text { Weight }\end{array}$ & $\begin{array}{c}\text { Composite } \\
\text { Metric-Weight }\end{array}$ \\
\hline \multirow{3}{*}{$\begin{array}{c}\text { Capital } \\
\text { Adequacy }\end{array}$} & Capital Adequacy Ratio & $\begin{array}{l}\text { Tier I \& Tier II Capital/ } \\
\text { Aggregate of Risk Weighted Assets }\end{array}$ & 0.7 & \multirow{3}{*}{0.2} \\
\hline & Debt-to-Equity & Borrowings/ Equity & 0.15 & \\
\hline & Coverage Ratio & $\begin{array}{l}\text { (Net Worth-Net Non Performing Assets)/ } \\
\text { Total Assets }\end{array}$ & 0.15 & \\
\hline \multirow{3}{*}{ Asset Quality } & $\begin{array}{l}\text { Net Non-Performing Asset/ } \\
\text { Net Loans }\end{array}$ & Net Non-Performing Loans/Net Loans & 0.1 & \multirow{3}{*}{0.225} \\
\hline & $\begin{array}{l}\text { Government Securities/ } \\
\text { Investment }\end{array}$ & $\begin{array}{l}\text { Government Securities/ } \\
\text { Total Investment }\end{array}$ & 0.3 & \\
\hline & Net Loan/Gross Loan & Net Loan/Grosss Loans & 0.6 & \\
\hline \multirow{3}{*}{$\begin{array}{l}\text { Management } \\
\text { Efficiency }\end{array}$} & Total Loan/Total Deposit & Total Loan/Total Deposit & 0.25 & \multirow{3}{*}{0.2} \\
\hline & Business Per Employee & $\begin{array}{l}\text { Total Loans and Total Despoit/ Number of } \\
\text { Employees }\end{array}$ & 0.25 & \\
\hline & Profit Per Employees & Profit Before Tax/Number of Employees & 0.5 & \\
\hline \multirow{4}{*}{$\begin{array}{l}\text { Earning } \\
\text { Quality }\end{array}$} & Return on Asset & Profit Before Tax/ Total Asset & 0.25 & \multirow{4}{*}{0.25} \\
\hline & Income Spread/Total Asset & $\begin{array}{l}\text { (Interest Icome-Interest Expense)/ } \\
\text { Total Asset }\end{array}$ & 0.25 & \\
\hline & Operating Profit/ Total Asset & Operating Profit/Total Assets & 0.25 & \\
\hline & Income to Cost Ratio & Net Income/Operatiing Expenses & 0.25 & \\
\hline \multirow{3}{*}{ Liquidity } & Cash asset/Total Assets Ratio & Cash asset/Total Assets & 0.25 & \multirow{3}{*}{0.1} \\
\hline & $\begin{array}{l}\text { Government Securities/ } \\
\text { Total Assets Ratio }\end{array}$ & Government Securities/Total Assets & 0.25 & \\
\hline & $\begin{array}{l}\text { Liquid Assets / } \\
\text { Total Deposit Ratio }\end{array}$ & Liquid Assets/Total Deposit & 0.5 & \\
\hline $\begin{array}{l}\text { Sensitivity to } \\
\text { Market Risk }\end{array}$ & Return on Asset/ Exchange Ratio & Return on Asset/Exchange Rate & 1.00 & 0.025 \\
\hline
\end{tabular}

Table 2: Categorisations of selected Listed Deposit Money Banks based on identified characteristics

\begin{tabular}{|c|c|c|c|c|c|c|}
\hline \multirow[b]{2}{*}{$\mathrm{S} / \mathrm{N}$} & \multicolumn{2}{|c|}{ Operating License } & \multicolumn{2}{|c|}{ Operating Structure } & \multicolumn{2}{|c|}{ Systemic Importance } \\
\hline & National & International & Holding & Non-Holding & $\begin{array}{l}\text { Domestic- } \\
\text { Systemically } \\
\text { Important }\end{array}$ & $\begin{array}{l}\text { Domestic-Non } \\
\text { Systemically } \\
\text { Important }\end{array}$ \\
\hline 1 & StanbicIBTC & Access & StanbicIBTC & Access & First & FCMB \\
\hline 2 & Sterling & Fidelity & FCMB & Fidelity & Zenith & StanbicIBTC \\
\hline 3 & Wema & FCMB & First & Union & Access & Sterling \\
\hline 4 & & Guaranty Trust & & UBA & Guaranty Trust & Wema \\
\hline 5 & & Union & & Zenith & Diamond & Fidelity \\
\hline 6 & & UBA & & Diamond & UBA & Union \\
\hline 7 & & First & & Sterling & & \\
\hline 8 & & Zenith & & Wema & & \\
\hline 9 & & Diamond & & Guaranty Trust & & \\
\hline
\end{tabular}

(Source: The Central Bank of Nigeria, 2017)

\section{Results and Discussions}

Results reported in table 3 reveal that Zenith bank International Plc had the highest average Capital Adequacy Ratio (CAR) of 25.9\%, closely followed by Fidelity bank Plc with CAR of 25.1\% and then Stanbic 
IBTC coming in third position with an average CAR of 22.2\%. A 7.1\% percentage point exists between the CAR of Zenith bank and the DMB with the lowest CAR. This implies that, during the period under review Zenith bank, Fidelity Bank and StanbicIBTC appeared to have very strong abilities to absorb losses arising from their risk assets. Using the Equity-to-Debt Ratio, Zenith Bank also reported the highest result with a staggering average figure of $907 \%$, followed by Union Bank with 334\%. Guaranty Trust Bank had the highest average coverage ratio of $16 \%$ with Wema Bank having the least figure at $4.7 \%$. Overall, Zenith Bank is rated first as the DMB with the highest weighted score of 0.3130, while Wema Bank is rated the least with 0.0375 .

From the results reported in table 4, it can be deduced that Wema Bank recorded the highest ratio of non-performing loans to net loan with a figure that stands tall at an average of $17.4 \%$, while United Bank for Africa had the least amount at 2.2\%. Zenith Bank had the staggering average ratio of Government Securities to total investment of $347.7 \%$, the highest in the pack, while Access Bank recorded the lowest at an average of $62.7 \%$. United Bank for Africa had the highest average of the ratio of net loan to gross loan of $97.8 \%$, a measure that reinforces the result of the bank using the ratio of non-performing assets to net loan. Overall, Zenith Bank is rated first as the DMB with the highest asset quality based on an overall weighted score of 0.3665, while Access Bank is rated in distant 12 th position.

Table 3: Results of Financial Health Metrics on Capital Adequacy

\begin{tabular}{|c|c|c|c|c|c|}
\hline \multirow[b]{2}{*}{ Banks } & \multicolumn{5}{|c|}{ Capital Adequacy } \\
\hline & CAR & EDR & $\begin{array}{l}\text { Cov } \\
\text { Ratio }\end{array}$ & $\begin{array}{c}\text { Overall } \\
\text { Weighted } \\
\text { Score } \\
\end{array}$ & Rank \\
\hline Access & 0.19 & 1.54 & 0.15 & 0.08 & 8 \\
\hline Zenith & 0.26 & 9.08 & 0.15 & 0.31 & 1 \\
\hline UBA & 0.20 & 2.22 & 0.12 & 0.10 & 5 \\
\hline GTB & 0.21 & 1.54 & 0.16 & 0.08 & 7 \\
\hline FCMB & 0.21 & 2.90 & 0.15 & 0.12 & 3 \\
\hline Union & 0.15 & 3.34 & 0.12 & 0.12 & 2 \\
\hline Diamond & 0.17 & 1.66 & 0.11 & 0.08 & 9 \\
\hline Sterling & 0.14 & 1.21 & 0.08 & 0.06 & 11 \\
\hline StanbicIBTC & 0.22 & 1.87 & 0.13 & 0.09 & 6 \\
\hline First & 0.19 & 2.85 & 0.10 & 0.12 & 4 \\
\hline Wema & 0.10 & 0.72 & 0.05 & 0.04 & 12 \\
\hline Fidelity & 0.25 & 0.90 & 0.15 & 0.07 & 10 \\
\hline
\end{tabular}
for the Selected Deposit Money Banks

Table 4: Results of Financial Health Metrics on Asset Quality for the Selected Deposit Money Banks

\begin{tabular}{|c|c|c|c|c|c|}
\hline \multirow{3}{*}{ Banks } & \multicolumn{5}{|c|}{ Asset Quality } \\
\hline & \multirow[b]{2}{*}{ NPA/NL } & \multirow[b]{2}{*}{ Gov/Invst } & \multicolumn{3}{|c|}{ Overall } \\
\hline & & & NL/TL & $\begin{array}{c}\text { Weighted } \\
\text { Score } \\
\end{array}$ & Rank \\
\hline Access & 0.03 & 0.63 & 0.97 & 0.17 & 12 \\
\hline Zenith & 0.03 & 3.48 & 0.97 & 0.37 & 1 \\
\hline UBA & 0.02 & 0.69 & 0.98 & 0.18 & 11 \\
\hline GTB & 0.04 & 1.60 & 0.96 & 0.24 & 6 \\
\hline FCMB & 0.03 & 0.94 & 0.97 & 0.19 & 9 \\
\hline Union & 0.26 & 1.14 & 0.83 & 0.19 & 10 \\
\hline Diamond & 0.04 & 1.81 & 0.96 & 0.25 & 4 \\
\hline Sterling & 0.04 & 1.75 & 0.96 & 0.25 & 5 \\
\hline StanbicIBTC & 0.05 & 2.41 & 0.95 & 0.29 & 3 \\
\hline First & 0.05 & 1.05 & 0.95 & 0.20 & 8 \\
\hline Wema & 0.17 & 1.36 & 0.88 & 0.21 & 7 \\
\hline Fidelity & 0.07 & 2.60 & 0.94 & 0.30 & 2 \\
\hline
\end{tabular}

(CAR stands for Capital Adequacy Ratio; DER stands for Debt-to-Equity Ratio; Cov ratio represents Coverage Ratio; NPA stands Non-Performing Assets; NL stands for Net Loans; Gov represent government securities; Invst stands for Total Investment; TL represents Total Loans)

Results shown in table 5 reveal that Wema Bank had the highest average ratio of total loan to total deposit of $152.9 \%$ during the period under consideration, an amount that is higher than that of the bank with the least figure by approximately 100 percentage points. Access banks reported the highest average business per employee of N940 million, while United Bank for Africa had the least amount of N251 million per employee. Guaranty Trust Bank stood as the bank with the highest average profit per employee of N34.87 million, the highest in that category. On an overall scale, the DMB with whose management was most efficient between 2010 and 2017 was Access Bank, followed by Guaranty Trust Bank in second position.

Results shown in table 6 demonstrate that almost all the banks had very low Return on Assets. The very huge assets these banks carry might be responsible for this situation. However, Guaranty Trust Bank had the highest average Return on Asset of 5.32\%. The results reported using the ratio of income spread to total assets followed almost the same pattern as Return on Assets for all the banks, with Diamond Bank coming top with 7.2\% and Guaranty Trust Bank (GTB) closely following. The performance metric of operating profit to total asset revealed that GTB had the highest, while Access bank is ranked second with 5.3\% and 4.9\% respectively. The average income-to-cost ratio for GTB was also the lowest during the period under consideration. In all, Union bank, StanbicIBTC and Wema appeared the top three DMBs with the highest Quality of Earnings between 2010 and 2017. 
Table 5: Results of Financial Health Metrics on Management Efficiency for the Selected Deposit Money Banks

\begin{tabular}{|c|c|c|c|c|c|}
\hline \multirow[b]{2}{*}{ Banks } & \multicolumn{5}{|c|}{ Management Efficiency } \\
\hline & TL/TDP & $\begin{array}{l}\text { B/Empl. } \\
\text { (Million) }\end{array}$ & $\begin{array}{c}\text { P/Empl } \\
\text { (Million) }\end{array}$ & $\begin{array}{c}\text { Overall } \\
\text { Weighted } \\
\text { Score } \\
\end{array}$ & Rank \\
\hline Access & 0.81 & 939.71 & 17.51 & 48.78 & 1 \\
\hline Zenith & 0.66 & 538.51 & 16.09 & 28.57 & 3 \\
\hline UBA & 0.53 & 251.34 & 4.08 & 13.00 & 12 \\
\hline GTB & 0.81 & 734.71 & 34.87 & 40.26 & 2 \\
\hline FCMB & 0.84 & 318.95 & 2.97 & 16.29 & 9 \\
\hline Union & 0.59 & 280.24 & 4.54 & 14.50 & 10 \\
\hline Diamond & 0.76 & 468.26 & 2.51 & 23.70 & 5 \\
\hline Sterling & 0.61 & 342.62 & 3.13 & 17.47 & 8 \\
\hline StanbicIBTC & 0.74 & 330.06 & 10.54 & 17.59 & 7 \\
\hline First & 0.83 & 550.22 & 6.04 & 28.16 & 4 \\
\hline Wema & 1.53 & 280.55 & 2.65 & 14.37 & 11 \\
\hline Fidelity & 0.71 & 347.23 & 3.94 & 17.79 & 6 \\
\hline
\end{tabular}

(Source: Annual Reports 2010-2017 \& Author's Computation 2019, aided by Ms-Excel,version 2016)
Table 6: Results of Financial Health Metrics on Earnings Quality for the Selected Deposit Money Banks

\begin{tabular}{|c|c|c|c|c|c|c|}
\hline \multirow{3}{*}{ Banks } & \multicolumn{6}{|c|}{ Earnings Quality } \\
\hline & \multirow[b]{2}{*}{ ROA } & \multirow[b]{2}{*}{ IS/TA } & \multirow[b]{2}{*}{$\mathrm{OP} / \mathrm{TA}$} & \multicolumn{3}{|c|}{ Overall } \\
\hline & & & & ITC & $\begin{array}{l}\text { Weighted } \\
\text { Score }\end{array}$ & Rank \\
\hline Access & 0.022 & 0.045 & 0.049 & 1.107 & 0.076 & 8 \\
\hline Zenith & 0.031 & 0.054 & 0.031 & 0.835 & 0.060 & 9 \\
\hline UBA & 0.017 & 0.040 & 0.017 & 1.183 & 0.079 & 7 \\
\hline GTB & 0.053 & 0.068 & 0.053 & 0.572 & 0.047 & 12 \\
\hline FCMB & 0.011 & 0.054 & 0.010 & 1.255 & 0.083 & 5 \\
\hline Union & 0.017 & 0.049 & 0.008 & 1.551 & 0.102 & 1 \\
\hline Diamond & 0.006 & 0.072 & 0.006 & 0.857 & 0.059 & 10 \\
\hline Sterling & 0.012 & 0.049 & 0.012 & 1.205 & 0.080 & 6 \\
\hline StanbicIBTC & 0.030 & 0.055 & 0.030 & 1.457 & 0.098 & 2 \\
\hline First & 0.015 & 0.061 & 0.015 & 0.836 & 0.058 & 11 \\
\hline Wema & 0.013 & 0.044 & 0.005 & 1.296 & 0.085 & 3 \\
\hline Fidelity & 0.013 & 0.044 & 0.013 & 1.263 & 0.083 & 4 \\
\hline
\end{tabular}

(Source: Annual Reports 2010-2017 \& Author's Computation 2019, aided by Ms-Excel,version 2016)

(TDP stands Total Deposit; B/Empl. represents Business Per Employees; P/Empl. stands for Profit per Employee while TL represents Total Loans; (ROA stands Return on Asset; IS represents Income Spread; TA stands for Total Assets; OP stands for Operating Profit, while CTI represents Income-to-Cost)

On liquidity, the results in table 7 provide evidence that UBA had the highest Cash Asset to Total Asset ratio of $22.31 \%$, implying that for every one naira of asset the bank had between 2010 and 2018,22 kobo constituted cash; followed by Stanbic IBTC with an average of $16.40 \%$. The latter bank also had very huge liquid assets in relation to total deposit of 79.5\%, a further evidence of the liquidity of this DMB. It is therefore not surprising that the Bank is ranked as the most liquid of all the selected DMBs considered in this study.

As reported in table 8, GTB appears to be the DMB whose return on asset is most sensitive to the vagaries in the foreign exchange market, with a sensitivity quotient of 0.000303 (3.03 basis point), while Diamond Bank is ranked the lowest with sensitivity quotient of 0.000042 ( 0.42 basis point).

Table 7: Results of Financial Health Metrics on Liquidity for the Selected Deposit Money Banks

\begin{tabular}{|c|c|c|c|c|c|}
\hline \multirow{3}{*}{ Banks } & \multicolumn{5}{|c|}{ Liquidity } \\
\hline & \multirow[b]{2}{*}{$\mathrm{CA} / \mathrm{TA}$} & \multirow[b]{2}{*}{ GS/TA } & \multicolumn{3}{|c|}{ Overall } \\
\hline & & & LA/TDP & $\begin{array}{c}\text { Weighted } \\
\text { Score }\end{array}$ & Rank \\
\hline Access & 0.151 & 0.110 & 0.299 & 0.043 & 12 \\
\hline Zenith & 0.156 & 0.197 & 0.441 & 0.062 & 9 \\
\hline UBA & 0.223 & 0.189 & 0.592 & 0.080 & 4 \\
\hline GTB & 0.138 & 0.196 & 0.511 & 0.068 & 7 \\
\hline FCMB & 0.108 & 0.155 & 0.394 & 0.053 & 11 \\
\hline Union & 0.075 & 0.311 & 0.599 & 0.079 & 5 \\
\hline Diamond & 0.144 & 0.258 & 0.460 & 0.066 & 8 \\
\hline Sterling & 0.118 & 0.334 & 0.501 & 0.073 & 6 \\
\hline StanbicIBTC & 0.164 & 0.326 & 0.795 & 0.104 & 1 \\
\hline First & 0.119 & 0.227 & 0.422 & 0.060 & 10 \\
\hline Wema & 0.089 & 0.267 & 0.700 & 0.088 & 3 \\
\hline Fidelity & 0.151 & 0.387 & 0.751 & 0.102 & 2 \\
\hline
\end{tabular}

Table 8: Results of Financial Health Metrics on Sensitivity to Market Risk for the Selected Deposit Money Banks

\begin{tabular}{lccc}
\hline & \multicolumn{3}{c}{ Liquidity } \\
\cline { 2 - 3 } Banks & $\begin{array}{c}\text { Sensitivity to } \\
\text { Market Risk }\end{array}$ & $\begin{array}{c}\text { Overall } \\
\text { Weighted } \\
\text { Score }\end{array}$ & Rank \\
\cline { 3 - 5 } \cline { 3 - 4 } Access & 0.000125 & 0.0000031 & 4 \\
Zenith & 0.000179 & 0.0000045 & 2 \\
UBA & 0.000103 & 0.0000026 & 5 \\
GTB & 0.000303 & 0.0000076 & 1 \\
FCMB & 0.000064 & 0.0000016 & 9 \\
Union & 0.000083 & 0.0000021 & 7 \\
Diamond & 0.000042 & 0.0000010 & 12 \\
Sterling & 0.000064 & 0.0000016 & 10 \\
StanbicIBTC & 0.000173 & 0.0000043 & 3 \\
First & 0.000084 & 0.0000021 & 6 \\
Wema & 0.000061 & 0.0000015 & 11 \\
Fidelity & 0.000072 & 0.0000018 & 8 \\
\hline (Source:Annual Reports 2010-2017 \& Author's Computation \\
2019, aided by Ms-Excel,version 2016) & &
\end{tabular}

(CA stands Cash Asset; TA stands for Total Assets; GS represent Government Securities; LA stands for Liquid Assets, while TDP represents Total Deposit.)

With financial health aggregate composite weighted scores of 49.1470, 40.6971, 29.3683, 28.5909 and 24.1565, Access Bank, Guaranty Trust Bank, Zenith, First Bank and Diamond Bank are ranked first, second, third, fourth and fifth respectively. These banks are considered financially healthier than the remaining seven banks. These are as shown in the results reported in table 9. The very high composite scores on Management Efficiency metric contribute significantly to these positions, especially for Access Bank and Guaranty Trust Bank. However, UBA, Union and Wema occupied the bottom three positions, judging by their low financial health aggregate composite weighted scores. They are ranked low because they performed poorly on management efficiency, despite sterling results from other metrics. For instance, Union bank that is 
rated second on capital adequacy and first on earnings quality falters on management efficiency and asset quality where it was ranked 10th position apiece.

Table 9: Results of Overall Financial Health using CAMELS for the Selected Listed DMBs

\begin{tabular}{|c|c|c|c|c|c|c|c|c|}
\hline \multirow[b]{2}{*}{ Banks } & \multicolumn{8}{|c|}{ CAMELS } \\
\hline & $\begin{array}{c}\text { Capital } \\
\text { Adequacy }\end{array}$ & $\begin{array}{c}\text { Asset } \\
\text { Quality }\end{array}$ & $\begin{array}{c}\text { Management } \\
\text { Efficiency }\end{array}$ & $\begin{array}{c}\text { Earnings } \\
\text { Quality }\end{array}$ & Liquidity & $\begin{array}{c}\text { Sensitivity to } \\
\text { Market Risk }\end{array}$ & $\begin{array}{c}\text { Composite } \\
\text { Score }\end{array}$ & Rank \\
\hline Access & 0.077 & 0.174 & 48.777 & 0.076 & 0.043 & 0.0000031 & 49.1470 & 1 \\
\hline Zenith & 0.313 & 0.367 & 28.568 & 0.060 & 0.062 & 0.0000045 & 29.3683 & 3 \\
\hline UBA & 0.098 & 0.179 & 13.002 & 0.079 & 0.080 & 0.0000026 & 13.4376 & 12 \\
\hline GTB & 0.081 & 0.239 & 40.263 & 0.047 & 0.068 & 0.0000076 & 40.6971 & 2 \\
\hline FCMB & 0.121 & 0.195 & 16.286 & 0.083 & 0.053 & 0.0000016 & 16.7377 & 9 \\
\hline Union & 0.125 & 0.194 & 14.495 & 0.102 & 0.079 & 0.0000021 & 14.9953 & 10 \\
\hline Diamond & 0.076 & 0.253 & 23.702 & 0.059 & 0.066 & 0.0000010 & 24.1565 & 5 \\
\hline Sterling & 0.058 & 0.249 & 17.474 & 0.080 & 0.073 & 0.0000016 & 17.9345 & 8 \\
\hline StanbicIBTC & 0.091 & 0.292 & 17.594 & 0.098 & 0.104 & 0.0000043 & 18.1788 & 7 \\
\hline First & 0.115 & 0.201 & 28.157 & 0.058 & 0.060 & 0.0000021 & 28.5909 & 4 \\
\hline Wema & 0.038 & 0.215 & 14.369 & 0.085 & 0.088 & 0.0000015 & 14.7940 & 11 \\
\hline Fidelity & 0.067 & 0.304 & 17.791 & 0.083 & 0.102 & 0.0000018 & 18.3472 & 6 \\
\hline
\end{tabular}

(Source:Annual Reports 2010-2017 \& Author's Computation 2019, aided by Ms-Excel,version 2016)

\section{Test of Hypotheses}

The results reported in tables 10,11 and 12 provide strong evidence of normality of the distribution of the data, as the Shapiro-Wilk statistics of 0.804 and 0.901 (for operating licence), 0.840, 0.843 (for operating structure), 0.829 and 0.948 (Systemic Importance) are not significant at 1\% and 5\% levels. With these results, the null hypotheses of normal distributions of data cannot be rejected. This provides the basis for the use of independent samples t-test of significance of equality of means. Reported results in table 13 provide further corroborative evidence that supports the appropriateness of the use of independent sample t-test of equality of means. The Levene's F-Statistics for the three bank characteristics are not statistically significant at $1 \%$ and $5 \%$. This presupposes that the null of hypothesis of equality of variance is well-supported.

Table 10: Results of Test of Normality of Distribution of data on Type of License using Composite Rating Score

\begin{tabular}{|c|c|c|c|c|}
\hline & \multirow{2}{*}{ Type of Licence } & \multicolumn{3}{|c|}{ Shapiro-Wilk } \\
\hline \multirow{3}{*}{$\begin{array}{l}\text { Composite } \\
\text { Rating } \\
\text { Score }\end{array}$} & & Statistic & $\mathrm{df}$ & Sig. \\
\hline & National License & 0.804 & 3 & 0.124 \\
\hline & International License & 0.901 & 9 & 0.259 \\
\hline
\end{tabular}

Table 11: Results of Test of Normality of Distribution of data on Operating Structure using Composite Rating Score

\begin{tabular}{|c|c|c|c|c|}
\hline & \multirow{2}{*}{ Operating Structure } & \multicolumn{3}{|c|}{ Shapiro-Wilk } \\
\hline & & Statistic & $\mathrm{df}$ & Sig. \\
\hline Composite & Holding Company & 0.840 & 3 & 0.213 \\
\hline Rating Score & Non-Holding Company & 0.843 & 9 & 0.062 \\
\hline
\end{tabular}


Table 12: Results of Test of Normality of Distribution of data on Systemic Importance using Composite Rating Score

\begin{tabular}{|c|c|c|c|c|}
\hline & \multirow{2}{*}{ Systemic Importance } & \multicolumn{3}{|c|}{ Shapiro-Wilk } \\
\hline & & Statistic & $\mathrm{df}$ & Sig. \\
\hline \multirow{2}{*}{$\begin{array}{l}\text { Composite } \\
\text { Rating Score }\end{array}$} & Systemically Important & 0.829 & 6 & 0.105 \\
\hline & Non-Systemically Important & 0.948 & 6 & 0.724 \\
\hline
\end{tabular}

Table 13: Results of Test of Equality of Variances using composite scores on bank characteristics

\begin{tabular}{|c|c|c|c|}
\hline & $\begin{array}{c}\text { Bank } \\
\text { Characteristics }\end{array}$ & F- Statistics & $p$-value \\
\hline Composite & Type of License & 4.031 & 0.072 \\
\hline Rating & Operating Structure & 1.446 & 0.257 \\
\hline Scores & Systemic Importance & 3.403 & 0.095 \\
\hline
\end{tabular}

(Source: Annual Reports 2010-2016 \& Author's Computation aided by SPSS version 20.0, 2019)

*** $p$-value $<0.01 ; * *$-value $<0.05$

\section{Hypothesis One:}

Ho: There is no significant difference between the financial health of International and National Licenced DMBs in Nigeria

Reported results in table 14 indicate that the Financial Health Composite Rating Score for DMBs operating with International Banking License is significantly the same as that of DMBs operating with National Banking Licence. This is because the t-statistic of 1.257 is not statistically significant at $1 \%$ and $5 \%$ to warrant the rejection of the null hypothesis. In other words, $p$-value $>.01$; $p$-value $>.05$ Consequently, the null hypothesis that there is no significant difference between the financial health of International and National Licenced Deposit Money Banks in Nigeria is accepted.

Table 14: Result of independent sample t-test of equality of means on hypothesis one

\begin{tabular}{|c|c|c|c|c|c|}
\hline & $\mathrm{t}$ & $p$-value & $\mathrm{df}$ & $\begin{array}{c}\text { Mean } \\
\text { Difference }\end{array}$ & $\begin{array}{l}\text { Std. Error } \\
\text { Difference }\end{array}$ \\
\hline Composite & & & & & \\
\hline $\begin{array}{l}\text { Rating } \\
\text { Scores }\end{array}$ & 1.257 & 0.237 & 10 & 9.19508 & 7.31331 \\
\hline
\end{tabular}

(Source: Annual Reports, 2010-2017 \& author's computation aided by SPSS Version 20, 2019)

*** $p$-value $<0.01 ; * * p$-value $<0.05$

\section{Hypothesis Two:}

Ho: There is no significant difference between the financial health of Holding and Non-Holding Company Structured DMBs in Nigeria.

Reported results in table 15 show that the Financial Health Composite Rating Score for DMBs operating as financial holding companies is significantly the same as those from DMBs not operating as financial holding companies. This is because the t-statistic of 0.462 is not statistically significant at $1 \%$ and $5 \%$ to justify the rejection of the null hypothesis. In other words, $p$-value $>.01 ; p$-value $>.05$. Therefore, the null hypothesis that there is no significant difference between the financial health of Holding and Non-Holding Company Structured Deposit Money Banks in Nigeria is accepted. 
Table 15: Result of independent sample t-test of equality of means on hypothesis two

\begin{tabular}{|c|c|c|c|c|c|}
\hline & $\mathrm{t}$ & p-value & $\mathrm{df}$ & $\begin{array}{c}\text { Mean } \\
\text { Difference }\end{array}$ & $\begin{array}{l}\text { Std. Error } \\
\text { Difference }\end{array}$ \\
\hline $\begin{array}{c}\text { Composite } \\
\text { Rating } \\
\text { Scores }\end{array}$ & 0.462 & 0.654 & 10 & 3.5950 & 7.7876 \\
\hline
\end{tabular}

(Source: Annual Reports, 2010-2017 \& author's computation aided by SPSS Version 20, 2019)

*** $p$-value $<0.01 ; * * p$-value $<0.05$

\section{Hypothesis Three}

Ho: There is no significant difference between the financial health of Domestic-Systemically Important and Domestic-Non-Systemically Important DMBs in Nigeria.

Reported results in table 16 demonstrate that the Financial Health Composite Rating Score for Domestic Systemically Important DMBs is significantly not the same as those for DMBs not designated as Domestic Systemically Important. This is because the t-statistic of 2.832 is statistically significant at $1 \%$ and $5 \%$ to support the rejection of the null hypothesis. In other words, $p$-value $>.01 ; p$-value $>.05$. Therefore, the null hypothesis that there is no significant difference between the financial health of Domestic-Systemically Important and Domestic-Non-Systemically Important Deposit Money Banks in Nigeria is not accepted.

Table 16: Result of independent sample t-test of equality of means on hypothesis three

\begin{tabular}{|c|c|c|c|c|c|}
\hline & $\mathrm{t}$ & $p$-value & $\mathrm{df}$ & $\begin{array}{c}\text { Mean } \\
\text { Difference }\end{array}$ & $\begin{array}{l}\text { Std. Error } \\
\text { Difference }\end{array}$ \\
\hline $\begin{array}{c}\text { Composite } \\
\text { Rating } \\
\text { Scores }\end{array}$ & 2.832 & $0.018^{* *}$ & 10 & .2317 & .08181 \\
\hline
\end{tabular}

Results from hypothesis one provides evidence that no significant difference exists between the financial health of International and National Licenced DMBs in Nigeria. This finding appears surprising, especially considering the industry weights of the banks operating with international banking authorisation, as compared to those with national banking licence. It would have been expected that combined banks with heavy-weights (such as Access Bank, Diamond, Fidelity, First, Zenith, UBA, Guaranty Trust, Union and FCMB) that have access to international banking markets, will post better performances on the six metrics of the model than StanbicIBTC, Wema and Sterling. This situation, in part, might be attributed to the economic recession of 2016-2017 during which the banks, across board, recorded depressing results.

In respect of hypothesis two, similar findings as hypothesis one were shown between the Financial Health of Holding and Non-Holding Company Structured DMBs in Nigeria. For hypothesis three, however, findings demonstrate that there is a significant difference in the Financial Health of Domestic-Systemically Important and Domestic Non-Systemically Important DMBs in Nigeria. The close monitoring and tighter regulatory surveillance by $\mathrm{CBN}$ of the banks in the former category might have been responsible for the results in hypothesis three. For instance, while national and international banks are required by the regulator to keep a minimum of 10 per cent and 15 per cent Capital Adequacy Ratio (CAR) respectively, D-SIBs are to maintain minimum of 15 per cent CAR and a ceiling of not more than 25 per cent of their qualifying capital (CBN, 2016).

It is crucial to note that the above results could not be situated within the context of existing cognate studies such as that of Iheanyi and Sotonye (2017); Onyema, Okey, Precious and Amadi (2018); Rahman and Islam (2018) Mulualem (2015) and Anteneh, Arega \& Yonas, (2011). The rationale is that these studies have research designs and methodologies that are different from that of this study.

Other reported results showed that Zenith bank is ranked first on capital adequacy, while Wema bank is ranked last. On asset quality metric, Zenith bank and Access Bank are ranked first and last respectively. While Access bank and UBA are ranked first and last on management efficiency respectively, Union and Guaranty Trust Bank are ranked first and last respectively on earning quality. The most liquid of the sampled bank is StanbicIBTC, as compared to Access bank that is adjudged to be the least liquid. Guaranty Trust bank is the bank whose earnings are most sensitivity to Market Risk of exchange rate. Overall, Access, Guaranty Trust Bank and Zenith are ranked in the top-three performing banks, while UBA, Wema and Union occupied positions 12,11 and 10 respectively. 


\section{Conclusions and Recommendations}

In spite of the preponderance of literature on the evaluation of the financial soundness of banks using the CAMELS Rating Model, very scanty pieces of evidence exist on the banking paradigm's application in DMBs based on bank characteristics such type of operating licence, type of operating structure and whether or not the banks are systemically important. Based on the above characteristics, this study, therefore, attempts to contribute to existing body of literature by assessing the financial health of these banks using secondary data gleaned from the annual reports of the banks and which covered 2010-2017, Findings indicates that no significant difference exists between the Financial Health of International and National Licenced DMBs in Nigeria. Further evidence shows that there is a significant difference between the Financial Health of Domestic-Systemically Important and Domestic Non-Systemically Important DMBs in Nigeria. Premised on these results, this study concludes that the financial health of DMBs do not differ based on type of operating licence and structure. However, their financial health only differ based on whether or not they are systemically important.

The findings of this study have implications for all the stakeholders of DMBs in Nigeria, especially the regulator. For the regulator, it complements the information that CBN may have by furnishing it with evidence-based information on the set of banks that are financially sound and healthy and the ones that are not, for an effective and proactive discharge of its regulatory responsibilities in order to ensure a sound financial system. For the managers of the DMBs that are ranked low, the findings are expected to galvanise them to evolve measures that will result in improved performance on all the six components of the CAMEL model. For investors, whether current or would be, the results of this study point to the fact that, they need to exercise caution and be very selective in choosing their banks to invest in.

Against the background of the above findings, this study recommends that the apex monetary authority should tighten its prudential guidelines and improve on its supervisory responsibilities of DMBs in Nigeria, especially the ones that were ranked low in order to engender a robust banking sector and sound financial system. It is also recommended that the management and board of directors of DMBs that were ranked low should embark on reforms that will help revamp their business models and operational processes in order to improve their ratings in the industry.

Using CAMELS rating model and based on certain operational and strategic characteristics, this study has made modest contributions to the body of knowledge by providing evidence that no significant difference exists between the financial health of International and National Licenced DMBs in Nigeria. It has also provided similar evidence between the financial health of Holding and Non-Holding Company structured DMBs. However, findings demonstrated that the financial health of Domestic-Systemically Important Banks is significantly different from that of Domestic-Non-Systemically Important Bank.

To enrich cognate literature, studies could be carried out with an extended sample size in the future, while also suggesting that a cross-country comparative evaluation of commercial banks can be undertaken.

\section{References}

1. Adeusi, S.O., Akeke, N.I., Adebisi, O.S. and Oladunjoye, O. (2014), "Risk Management and Financial Performance of Banks in Nigeria", European Journal of British Management, 6, pp.336-342

2. Alemu, M. and Aweke, M. (2017), "Financial performance analysis of private commercial banks of Ethiopia: CAMEL ratings", International Journal of Scientific and Research Publications, 7(10), pp. 367-395

3. Altan, M., Yusufazari, H. and Bedük, A. (2014), "Performance Analysis of Banks in Turkey Using CAMEL Approach. In Proceedings of International Academic Conferences (No. 0902916)", International Institute of Social and Economic Sciences.

4. Anteneh, G., Arega, S., and Yonas, M. (2011). Health check-up of Commercial Banks in Ethipia. Proceedings of the National Conference on 'Loan and Saving: the Role in Ethiopian Socioeconomic Development', 15-16 February 2013, Haramaya, Ethiopia.

5. Azizi.M and Sarkani.Y.A (2014), Review financial performance of MELLAT Bank According to CAMEL Model Journal of multidisciplinary research, 3(1), pp.32-42.

6. Bodla, B. S., and Verma, R. (2006), "Evaluating performance of banks through CAMEL Model: A case study of SBI and ICICI", The IUP Journal of Bank Management, 3, pp. 49-63.

7. Central Bank of Nigeria (2010), "CBN Scope, Conditions \& Minimum standards for commercial banks Regulations No. 01, 2010", Retrieved on 22 February, 2019, from https://www.cbn.gov.ng/OUT/2010/CIRCULARS/BSD/COMMERCIAL\%20BANKING\%20LICENSING\%20REGULATIONS\% 20-\%2OFINAL\%20RELEASED.PDF

8. Central Bank of Nigeria (2010), "Circular to all banks and discount houses review of Universal Banking Model".Retrieved on 22 February, 2019, from https://www.proshareng.com/admin/upload/reports/2754.pdf

9. Central Bank of Nigeria (2014), "Circular to all banks and financial institution on guidelines for licensing and regulation of financial holding companies in Nigeria", Retrieved from https://www.cbn.gov.ng/out/2014/fprd/holdco\%20regulation\%20(cleaned)\%20\%20final\%20for\%20issuance\%203.pdf on 22 February, 2019.

10. Central Bank of Nigeria (2014), "Framework for the regulation and supervision of Domestic Systemically Important Banks (SIBS) in Nigeria", Retrieved on 22 February, 2019, from https://www.cbn.gov.ng/out/2014/bsd/approved\%20sib\%20supervisory\%20framework\%20.pdf 
11. Central Bank of Nigeria (2017), "List of deposit money banks and financial holding companies operating in Nigeria as at December 29, 2017", Retrieved on 22 February, 2019, from

https://www.cbn.gov.ng/out/2018/fprd/updated\%20list\%20of\%20commercial\%20banks\%20as\%20at\%20december\% 2029\%202017.pdf

12. Chaudhuri, B. (2018), "A Comparative Analysis of SBI and ICICI: Camel Approach", International Journal of Research in Management, Economics and Commerce, 8(1), pp. 151-156

13. Chien, T., and Danw, S. Z. (2004), "Performance Measurement of Taiwan Commercial Banks", International Journal of Productivity and Performance Management, 53(5), pp.425-434.

14. Cooper, D. and Schindler, P. (2014),"Business research methods", Boston: Irwin McGraw Hill.

15. Currie, C. V. (2005), "Towards a General Theory of Financial Regulation: Predicting, Measuring and Preventing Financial Crises (May 2005)", UTS Working Paper No. 142. Available at SSRN: https://ssrn.com/abstract=877035 or http://dx.doi.org/10.2139/ssrn.877035

16. Dash, M. and Das, A. (2009), "A CAMELS Analysis of the Indian Banking Industry", Social Science Research Network paper no. 1666900. http://www.ssrn.com/

17. Echekoba, F. N., Egbunike, C. F., and Ezu, K. G. (2014), "Determinants of Bank Profitability in Nigeria: Using Camel Rating Model (2001-2010)", Journal of Business and Management, 16(9), pp.44-50.

18. Federal Financial Institutions Examination Council (1979), "Statement of Policy on Uniform Financial Institutions Rating System", The United States: Federal Deposit Insurance Corporation (FDIC).

19. Federal Financial Institutions Examination Council (1997), "Statement of Policy on Uniform Financial Institutions Rating System", The United States: Federal Deposit Insurance Corporation (FDIC).

20. Funso, T. K., Kolasde, A.R., and Ojo, O.M. (2012), "Credit Risk and Commercial Banks' Performance in Nigeria: A Panel Model Approach", Australian Journal of Business and Management Research, 2(2), 31-38.

21. Grier, W. A. (2007), "Credit Analysis of Financial Institutions (2nd ed.)", Euromoney Institution Investor PLC.

22. Iheanyi, I.H. and Sotonye, I. (2017), "Assessing the Performance of Nigeria's Bank through Camel Model", Journal of Accounting and Financial Management, 3(1), pp. 14-22.

23. Jain, C. and Jaiswal, A. (2016), "A Comparative Study of Financial Performance of SBI and ICICI Banks in India", International Journal of Scientific Research in Computer Science and Engineering, 4(3), pp.2320-7639.

24. Kothari, C.R. and Garg, G. (2016), "Research methodology". Mumbai: New Age International Publishers.

25. Kumbirai, M. and Webb, R. (2010), "A financial Ratio Analysis of Commercial Bank Performance in South Africa", African Review of Economics and Finance, 2(1), 30-53

26. Lucky, L.Y. and Akani, H.W. (2017), "Comparative analysis of Commercial Banks Soundness: A CAMELS Study of Nigerian Pre and Post Consolidation Era", Research Journal on Finance and Accounting, 8(20), 149-173

27. Manju, R.B. and Ashok, K. (2017), "Adequacy of camels rating system in measuring the efficiency of banking industry: a retrospect", International Journal of Research in Arts and Science, 3 (Special Issue), 3-6

28. Marco D. A. and Luciano M. (2015), "Stakeholder management and performance measurement systems in banks", Retrieved on 25 February, 2019, from

https://www.researchgate.net/publication/280227347 Stakeholder Management and Performance Measurement in B $\underline{\text { anks }}$

29. Mulualem, M. (2015), "Analyzing Financial Performance of Commercial Banks in Ethiopia: CAMEL Approach. (Master thesis)", Addis Abiba University.

30. Nimalathasan, (2008), "A Comparative Study of Financial Performance of Banking Sector in Bangladesh - An Application of Camels Rating System", Annals of University of Bucharest, Economic and Administrative Series, 2, 141-152.

31. Okey-Nwala, P.O. (2018),"Financial soundness of deposit money banks in Nigeria. An application of camels and bankometer models",. (unpublished doctoral thesis). Rivers state university, Port Harcourt 2018.

32. Onyema, J.I., Okey, N., Precious, O. and Amadi S. N. (2018), "Evaluation of financial soundness of selected commercial banks in Nigeria: An application of Bankometer S-score model", Journal of Financial Marketing, 2(4), pp.22-25.

33. Opez, J.A. (1999), Using CAMELS Ratings to Monitor Bank Conditions. FRBSF Economic Letter.

34. Osuagwu, L. (2006), Business research methodology. Lagos: Grey Resources Limited.

35. Premium Times (2013). CBN moves to insulate eight top Nigerian banks from distress. Retrieved from https://www.premiumtimesng.com/business/144950-exclusive-cbn-moves-insulate-eight-top-nigerian-banksdistress.html, on 22 February, 2019.

36. Premium Times (2018). Nigeria's Central Bank takes over Skye Bank. Retrieved on 22 February, 2019, from https://www.premiumtimesng.com/news/headlines/284921-breaking-nigerias-central-bank-takes-over-skye-bank.html

37. Rahman, M.Z and Islam, M.S. (2018), "Use of CAMEL Rating Framework: A Comparative Performance Evaluation of selected Bangladeshi Private Commercial Banks", International Journal of Economics and Finance, 10(1), pp.120-128

38. Reddy, K.S. (2012), "Relative Performance of Commercial Banks in India using CAMEL Approach", Research Journal of Economic and Business Studies, 1(4), pp.1-10.

39. Rozzani, N. \& Abdul Rahman, R. (2013), "Determinants of Bank Performance: Conventional versus Islamic (Penentu Prestasi Bank: Konvensional berbanding Islam)", Jurnal Pengurusan , 39, pp.129 - 139

40. Said, R. M., and Tumin, M. H. (2011), "Performance and financial ratios of commercial banks in Malaysia and China", International Review of Business Research Papers, 7(2), pp.157-169.

41. Samuel, E.M. (2018), "Comparative Performance Evaluation of Selected Commercial Banks in India using CAMELS Rating Model", International Journal of Global Sustainability, 2(1), 24-38.

42. Sinkey, J.F. (1992). Commercial Bank Financial Management. Maxwell: MacMillian

43. Srinivasan, and Saminathan, Y.P. (2016), "A Camel Model Analysis of Public, Private and Foreign Sector Banks in India", Pacific Business Review International, 8(9), pp.45-57. 
44. Suresh, C. \& Bardastani, M. (2016), "Financial Performance of Selected Conventional And Islamic Banks In Kingdom Of Bahrain - A CAMEL Ranking Based Approach", European Journal of Economic, Law and Politics, 1(1), 23-59.

45. Uyen, D. (2011), "The Camel Rating System in Banking Supervision A Case Study (Published thesis)". Retrieved from on 24 February, 2019, from https://www.theseus.fi/bitstream/handle/10024/38344/Dang Uyen.pdf

46. Yuksel, S., Dincer, H., and Hacioglu, U. (2015), “CAMELS-based Determinants for the Credit Rating of Turkish Deposit Banks", International Journal of Finance \& Banking Studies, 4(4), 23-38. 